\title{
Bagaimana Media Memberitakan Produk Pangan? Analisis Isi Artikel Media Daring Tentang Susu Kental Manis
}

\section{How Media Portray Food Products: A Content Analysis of Articles about Sweetened Condensed Milk in Online Media}

\author{
Dien Anshari ${ }^{1}$, Mochamad Wachyu ${ }^{2}$, Nadia H. Qatrunnada ${ }^{2}$, Ahmad Syafiq ${ }^{3}$ \\ ${ }^{1}$ Departemen Pendidikan Kesehatan dan Ilmu Perilaku, Fakultas Kesehatan Masyarakat Universitas \\ Indonesia \\ ${ }^{2}$ Laboratorium Teknologi Pendidikan dan Komunikasi Kesehatan, Fakultas Kesehatan Masyarakat \\ Universitas Indonesia \\ ${ }^{3}$ Pusat Kajian Gizi dan Kesehatan, Fakultas Kesehatan Masyarakat Universitas Indonesia \\ (email penulis korespondensi: anshari@ui.ac.id, no.telepon: +6221-786-3475)
}

\begin{abstract}
ABSTRAK
Latar Belakang: Media massa dapat menentukan agenda publik dan mengarahkan cara pandang publik terhadap isu tertentu.

Tujuan:Penelitian ini bertujuan menggambarkan bagaimana media daring membingkai susu kental manis (SKM) sebagai salah satu produk pangan.

Metode: Penelitian ini menggunakan pendekatan analisis isi kuantitatif dalam ilmu komunikasi. Data untuk penelitian berupa semua artikel yang memuat frase"susu kental manis" yang terbit sepanjang 2016-2017 di situs media daring kompas.com ( $n=64)$, tempo.co $(n=49)$, detik.com $(n=142)$ dan vemale.com $(\mathrm{n}=120)$.

Hasil: Dari total 375 artikel tentang SKM, ada 34 artikel dengansentimen negatif, 24positif, sedangkan sisanya netral. SKM dibingkai secara negatif karena tinggi kandungan gula dan lemak, tidak termasuk produk susu, serta dapat menyebabkan diabetes, obesitas, masalah pencernaan, dan kerusakan gigi.Sementara SKM dibingkai secara positif karena dapat meningkatkan cita rasa makanan/minuman, harganya terjangkau, termasuk kebutuhan pokok, serta merupakan sumber energi dan protein. Sebagian bingkai negatif terhadap SKM baru ditemukan pada 2017. Penerbitan artikel dengan bingkai negatif terlihat memiliki pola tertentu dan tidak dilandasi kasus spesifik.

Kesimpulan: Media daring dalam membingkai SKM terlihat mengabaikan prinsip baku jurnalisme seperti dampak (significance), urgensi, dan verifikasi faktual. Penelitian dengan pendekatan politik ekonomi bisa menggali lebih dalam mekanisme maupun motif media daring dalam membuat artikel tentang produk pangan.
\end{abstract}

Kata kunci: Komunikasi kesehatan, gizi masyarakat, jurnalisme, kebijakan

\section{ABSTRACT}

Background: The news media can shape public agenda and perspective on a particular issue.

Objective: To analyze how online media portrayed sweetened condensed milk (SKM) as a food product.

Methods: We content analyzed all articles about SKM from 4 online media in Indonesia published in 2016-2017. All articles were reliably coded for frequency, media sources, type, tone, and frames.

Results: From a total of 375 articles found, 24 were framed positively, 34 were framed negatively, while the rest were neutral. SKM was positively framed as it enhances flavor, affordable, high usage, and a source of energy and protein. While SKM was framed negatively because of high sugar and fat content, is not dairy products, and can cause diabetes, obesity, digestive problems, and tooth decay. Some negative frames of SKM were only used in 2017. Timeline for articles with negative frames appear to have a certain pattern and not based on a specific case.

Conclusion: In framing SKM, online news media seems to ignore the principles of journalism such as impact (significance), urgency, and factual verification. Further research is needed to investigate the political economy of online media in telling stories about food products.

Keywords: Health communication, nutrition, journalism, policy 


\section{LATAR BELAKANG}

Media massa dipercaya mempunyai peran tertentu dalam membantu publik melakukan konstruksi terhadap realitas sosial. ${ }^{1,2}$ Melalui seleksi topik berita, media dapat menentukan agenda publik (agenda setting) dengan mengidentifikasi topik apa yang paling penting untuk diberitakan. ${ }^{3,4}$ Selain itu, media juga dapat melakukan pembingkaian (framing) yang bertujuan untuk mengarahkan bagaimana publik sebaiknya melihat dan memikirkan tentang isu yang diangkat. ${ }^{5-7}$

Pembingkaian oleh media diejawantahkan oleh jurnalis yang menulis laporan untuk pembaca umum. Jurnalis juga harus memadatkan dan menyederhanakan isu yang kompleks agar laporan yang mereka tulis dapat mudah dimengerti. Karena itu, jurnalis secara rutin membuat keputusan subyektif tentang dimensi dan karakteristik apa dari suatu isu yang layak diketahui pembaca, sudut pandang apa atau siapa yang harus ditekankan, dan yang mana yang harus dihilangkan. ${ }^{8}$ Melalui proses seleksi semacam ini, jurnalis secara tidak langsung telah merumuskan masalah sekaligus menawarkan solusinya. ${ }^{9}$

Media dan jurnalis memahami bahwa tidak semua peristiwa dapat ataupun layak diberitakan. Kajian-kajian dari ilmuwan komunikasi menyepakati hirarki unsur-unsur dalam suatu berita sebagai berikut: 1) Kesegeraan (immediacy); 2) Keterkenalan (prominence); 3) Dampak/konsekuensi; 4) Kebaruan/keanehan; 5) Kedekatan; 6) Kemanusiaan dan emosi; 7) Konflik; 8) Pendidikan/pembelajaran; 9) Peristiwa semu (pseudo-events); dan 10) Minat masyarakat (public interests). ${ }^{10-14}$ Dalam hal ini, media massa memiliki kekuasaan untuk menentukan peristiwa mana yang akan dijadikan berita di antara banyak peristiwa yang terjadi. Pada era sebelum media berbasis internet berkembang, pemilihan berita ini selain terkait dengan agenda setting dari media yang bersangkutan, juga karena keterbatasan ruang yang dimiliki oleh media tersebut. ${ }^{1}$ Apakah kemudian prinsip yang sama berlaku bagi media-media dalam jaringan (daring) masih belum banyak diteliti.

Pemberitaan mengenai produk pangan biasanya terjadi ketika ada kelangkaan (terutama jika produk pangan tersebut termasuk bahan kebutuhan pokok), kebahayaan (misalnya jika ada kasus keracunan atau jika produk tersebut berbahaya untuk dikonsumsi), kebaruan (misalnya jika ada produk baru, atau ada manfaat baru yang ditemukan dari suatu produk). Susu adalah salah satu dari sembilan barang kebutuhan pokok yang diperlukan masyarakat, seperti tertuang dalam Keputusan Menteri Perindustrian dan Perdagangan No. 115 tahun 1998 tentang Jenis Barang Kebutuhan Pokok Masyarakat. ${ }^{15}$ Namun, belum ada penelitian yang menelisik berapa banyak dan bagaimana media massa memuat berita mengenai susu maupun produk turunannya seperti susu formula, susu dalam kemasan, ataupun susu kental manis (SKM). Pada medio 2017, media massa daring (online) memuat berita-berita tentang bahaya mengonsumsi SKM. Padahal, peredaran SKM di Indonesia telah diatur dalam Peraturan Kepala Badan Pengawas Obat dan Makanan (BPOM) No. 1 tahun 2015 tentang Kategori Pangan. ${ }^{16}$ Menurut peraturan tersebut, SKM didefinisikan sebagai: "Produk susu berbentuk cairan kental yang diperoleh dengan menghilangkan sebagian air dari campuran susu dan gula hingga mencapai tingkat kepekatan tertentu; atau merupakan hasil rekonstitusi susu bubuk dengan penambahan gula, dengan atau tanpa penambahan bahan lain. Gula yang ditambahkan harus dapat mencegah pembusukan. Produk dikemas secara kedap (hermetis) dan dipasteurisasi." 16

Guna mendapatkan gambaran yang lebih komprehensif akan pemberitaan mengenai SKM, perlu dilakukan penelitian yang dapat melihat jumlah maupun isi pemberitaannya secara lebih sistematis. Hasil dari penelitian ini 
dapat menjadi masukan bagi pembaca dalam menerima informasi dari media daring, juga bagi produsen dalam memasarkan produknya, serta bagi jurnalis dalam menyampaikan informasi terkait produk pangan kepada masyarakat. Pertanyaan umum yang dijawab dalam penelitian ini adalah bagaimana media daring memberitakan SKM? Tujuan ini akan dicapai dengan mengevaluasi artikel-artikel mengenai SKM dengan pendekatan analisis isi (content analysis) kuantitatif dalam ilmu komunikasi massa. Analisis isi akan mencakup kuantitas artikel mengenai SKM, sentimen penulisan artikelnya, bagaimana pembingkaian terhadap SKM dilakukan, dan bagaimana perbandingan isi artikel antar periode tahun terbit dan antar media.

Adapun pertanyaan-pertanyaan spesifik yang akan dijawab dalam penelitian ini adalah: 1) Selama periode dari 1 Januari 2016 sampai dengan 31 Desember 2017, seberapa sering media daring memuat artikel tentang SKM?; 2) Bagaimana gambaran sentimen penulisan dari artikel-artikel tersebut? (positif, negatif, netral); 3) Bagaimana gambaran pembingkaian SKM selama periode tersebut?; dan 4) Bagaimana perbedaan pemberitaan antar periode dan antar media daring?

\section{METODE}

\section{Seleksi media daring}

Penelitian ini mengambil datanya dari artikel-artikel yang diterbitkan oleh media daring (selanjutnya disebut sebagai media) dengan kriteria inklusi sebagai berikut:

1. Telah berkiprah lebih dari lima tahun;

2. Terdaftar di Dewan Pers;

3. Mempunyai struktur redaksi yang jelas tercantum di situsnya;

4. Memiliki alamat fisik yang tercantum di situsnya;

5. Mempunyai struktur kepemilikan yang jelas.

Dari kriteria tersebut di atas, media daring yang terpilih menjadi obyek analisis dalam penelitian ini adalah Kompas (kompas.com),
Tempo (tempo.co), Detik (detik.com), dan Vemale (vemale.com).

\section{Seleksi artikel}

Penelitian ini mengambil artikel-artikel dari media tersebut di atas dengan batasan tahun penerbitan 2016 dan 2017 saja. Artikel diperoleh dengan cara sebagai berikut:

1. Menelusuri menu pencarian pada situs media yang dimaksud dengan menggunakan kata kunci "susu kental manis".

2. Menggunakan fitur pencarian lanjutan (advanced search) pada mesin pencari Google jika hasil pencarian pada situs resmi media daring tidak dapat memuat semua artikel pada periode penerbitan artikel selama dua tahun (mulai dari tanggal 1 Januari 2016 hingga 31 Desember 2017).

\section{Pengembangan daftar kode (codebook)}

Daftar kode dibuat berdasarkan variabelvariabel yang akan dianalisis, meliputi sumber media daring, periode artikel diterbitkan, jenis artikel yang diterbitkan, sentimen penulisan artikel, serta bagaimana pembingkaian mengenai SKM. Daftar kode pembingkaian tentang susu kental manis dikembangkan dari analisis terhadap $10 \%$ jumlah total artikel yang dipilih secara acak dan proporsional berdasarkan media dan tahun penerbitan. Daftar kode selengkapnya dapat dilihat pada Tabel 1.

\section{Reliabilitas antar penyelisik}

Empat penyelisik dilatih untuk menggunakan daftar kode yang telah dikembangkan. Tingkat keterpercayaan antar penyelisik (intercoder reliability) diuji dengan cara keempat peneliti melakukan kodifikasi pada $20 \%$ artikel dari masing-masing media dengan proporsi yang sama antar periode. Hasil kodifikasi oleh keempat penyelisik pada artikel yang sama tersebut kemudian diuji memakai Krippendorff's Alpha yang menghasilkan skor 
berkisar antara 0.70 hingga 1.00 dengan skor rata-rata sebesar 0.83 , yang berarti di atas acuan batas skor reliabilitas yang dianjurkan sebesar minimal 0.667. ${ }^{17}$

Tabel 1. Daftar kode pembingkaian narasi tentang susu kental manis

\section{Bingkai Negatif}

Karies gigi: Konsumsi SKM dapat menyebabkan karies gigi

Pencernaan: Konsumsi SKM dapat menyebabkan masalah pencernaan

Obesitas: Konsumsi SKM dapat menyebabkan obesitas

Diabetes: Konsumsi SKM dapat menyebabkan diabetes

Bukan susu: SKM bukan termasuk kategori produk susu

Tinggi lemak: Produk SKM memiliki kandungan lemak yang tinggi

Tinggi kalori/gula: Produk SKM memiliki kandungan kalori/gula yang tinggi

\section{Bingkai Netral}

Resep hidangan: SKM merupakan bahan campuran hidangan

Promosi produk: Produk SKM sedang ada potongan harga

\section{Bingkai Positif}

Sumber energi dan protein: Produk SKM adalah salah satu sumber energi dan protein

Sesuai aturan: Produk SKM yang beredar sesuai dengan peraturan yang berlaku

Terjangkau: SKM merupakan produk pangan yang terjangkau (murah dan mudah di dapat)

Bahan makanan pokok: SKM adalah salah satu bahan makanan pokok

Meningkatkan cita rasa: SKM dapat menambah cita rasa hidangan

\section{HASIL}

Terhitung dari tanggal 1 Januari 2016 sampai dengan tanggal 31 Desember 2017, ditemukan sebanyak 375 artikel yang memuat frasa "susu kental manis" yang diterbitkan oleh keempat media yang menjadi obyek penelitian. Dari jumlah tersebut, sebanyak 203 artikel diterbitkan pada tahun 2016, dan sebanyak 172 artikel diterbitkan pada tahun 2017.

Berdasarkan sumber media daring yang menerbitkannya, ditemukan sebanyak 64 artikel yang diterbitkan oleh Kompas, ada 49 artikel yang diterbitkan oleh Tempo, ada 142 artikel yang diterbitkan oleh Detik, dan ada
120 artikel yang diterbitkan oleh Vemale (lihat Tabel 2). Sementara dilihat dari jenis artikelnya, ditemukan sebanyak 290 artikel yang tidak tergolong sebagai artikel berita, atau merupakan artikel non berita (seperti resep hidangan, dan promosi produk), sementara ada 85 artikel lainnya yang tergolong sebagaiartikel berita dan opini (lihat Tabel 3).

Dilihat dari sentimen penulisan artikelnya, pada tahun 2016 ditemukan sebanyak 16 artikel dengan sentimen penulisan yang negatif, 175 artikel dengan sentimen penulisan yang netral, dan 12 artikel dengan sentimen penulisan yang positif. Sedangkan pada tahun 2017, ditemukan sebanyak 18 artikel dengan 
sentimen penulisan yang negatif, 142 artikel dengan sentimen penulisan yang netral, dan 12

Tabel 2. Jumlah artikel berdasarkan media dan tahun terbit

\begin{tabular}{lccc}
\hline \multirow{2}{*}{ Media } & \multicolumn{2}{c}{ Tahun } & \multirow{2}{*}{ Total } \\
\cline { 2 - 3 } & 2016 & 2017 & \\
\hline Kompas & 32 & 32 & 64 \\
Tempo & 29 & 20 & 49 \\
Detik & 78 & 64 & 142 \\
Vemale & 64 & 56 & 120 \\
\hline \multicolumn{1}{c}{ Total } & 203 & 172 & 375 \\
\hline
\end{tabular}

Tabel 3. Jenis artikel berdasarkan media

\begin{tabular}{lccc}
\hline \multirow{2}{*}{ Media } & \multicolumn{2}{c}{ Jenis artikel } & \\
\cline { 2 - 3 } & $\begin{array}{c}\text { Non } \\
\text { berita }\end{array}$ & $\begin{array}{c}\text { Berita/ } \\
\text { Opini }\end{array}$ & Total \\
\hline Kompas & 40 & 24 & 64 \\
Tempo & 37 & 12 & 49 \\
Detik & 101 & 41 & 142 \\
Vemale & 112 & 8 & 120 \\
\hline \multicolumn{1}{c}{ Total } & 290 & 85 & 375 \\
\hline
\end{tabular}

Pembingkaian SKM dalam artikel-artikel yang ditelisik secara umum dapat dikelompokkan ke dalam tiga kategori: Bingkaiyang negatif, bingkai yang netral, dan bingkai yang positif (lihat Tabel 1 untuk contoh-contoh kategori pembingkaian dan definisinya). Dalam satu artikel, bisa saja ada satu atau lebih bingkai, atau tidak ada pembingkaian sama sekali.

Pembingkaian SKM secara negatif ditemukan sebanyak 11 kali pada 2016 dan meningkat menjadi 40 kali pada 2017. Sementara pembingkaian berkategori netral ditemukan sebanyak 172 kali pada 2016 dan turun menjadi 135 kali pada 2017. Sedangkan pembingkaian SKM secara positif ditemukan sebanyak 46 kali pada 2016 dan naik sedikit menjadi 49 kali pada tahun berikutnya (lihat artikel dengan sentimen penulisan yang positif (lihat Tabel 4).

Tabel 5).

Untuk perbandingan antar media daring, dari sisi jumlah artikel yang diterbitkan setiap tahunnya, hanya Kompas yang jumlah artikelnya tetap sama antara tahun 2016 dan 2017, yaitu masing-masing 32 artikel. Sementara tiga media daring lainnya menunjukkan penurunan jumlah artikel mengenai SKM: Tempo berkurang dari 29 menjadi 20 artikel; Detik berkurang dari 78 menjadi 64 artikel; dan Vemale berkurang dari 64 menjadi 56 artikel (lihat Tabel 2). Sedangkan dari sisi jenis artikelnya, Detik menjadi media dengan jumlah artikel berita/opini paling banyak (41), disusul oleh Kompas (24), Tempo (12), dan Vemale (8).

\section{DISKUSI}

Penelitian ini menemukan sejumlah 375 artikel yang memuat frasa "susu kental manis" yang terbit pada periode 2016 sampai 2017 dari empat media daring populer di Indonesia. Dari jumlah tersebut, cukup banyak artikel yang tergolong berita/opini $(n=85)$, meskipun selama periode penelitian tidak ditemukan kasus spesifik yang berdampak kesehatan sebagai akibat konsumsi SKM (misalnya, keracunan) yang dapat menjadi landasan pemenuhan unsur pokok kelayakan berita. ${ }^{10,13}$

Dari sisi frekuensi artikel berdasarkan sentimen penulisan dan tahun terbitnya, studi ini menemukan peningkatan frekuensi artikel dengan sentimen negatif (dari 2016 ke 2017) pada Kompas dan Vemale, sementara hal yang sebaliknya ditemukan pada Tempo dan Detik. Sedangkan sentimen positif ditemukan meningkat pada Kompas, Tempo, dan Vemale, namun menurun pada Detik (lihat Tabel 4). Pola sentimen yang tak beraturan ini, baik antar periode maupun antar media, menunjukkan adanya perbedaan pembingkaian oleh media dalam mengangkat isu SKM, sehingga penelitian lanjutan layak dilakukan 
untuk menginvestigasi bagaimana media

daring memproduksi artikel untuk diterbitkan.

Tabel 4. Sentimen artikel berdasarkan media dan tahun terbit

\begin{tabular}{l|ccc|ccc|c}
\hline \multirow{2}{*}{ Media } & \multicolumn{3}{|c|}{ Sentimen (2016) } & \multicolumn{3}{c|}{ Sentimen (2017) } & \multirow{2}{*}{ Total } \\
\cline { 2 - 6 } & Negatif & Netral & Positif & Negatif & Netral & Positif & \\
\hline Kompas & 3 & 28 & 1 & 9 & 21 & 2 & 64 \\
Tempo & 4 & 25 & 0 & 1 & 18 & 1 & 49 \\
Detik & 7 & 66 & 5 & 5 & 57 & 2 & 142 \\
Vemale & 2 & 56 & 6 & 3 & 46 & 7 & 120 \\
\hline \multicolumn{1}{c}{ Total } & 16 & 175 & 12 & 18 & 142 & 12 & 375 \\
\hline
\end{tabular}

Dari sisi pembingkaian, hasil penyelisikan menunjukkan beberapa pembingkaian negatif yang baru muncul di tahun 2017, seperti pembingkaian SKM sebagai produk yang dapat menyebabkan karies gigi, obesitas, dan diabetes. Selain itu, ditemukan pula pembingkaian negatif yangsudah ada sejak tahun 2016, tetapi melonjak frekuensinya di tahun 2017,seperti pembingkaian SKM sebagai produk yang tinggi kalori/gula, dan pembingkaian SKM sebagai bukan produk susu. Sementara pembingkaian positif yang baru muncul pada 2017 hanyalah mengenai SKM sebagai produk yang telah memenuhi peraturan yang berlaku.

Melonjaknya frekuensi pembingkaian negatif pada SKM (dari hanya 11 kali pada 2016 menjadi sebanyak 40 kali pada 2017) tanpa didasari oleh adanya kasus spesifik yang memenuhi unsur dampak, kebahayaan, dan kesegeraan, dapat menimbulkan pertanyaan lebih lanjut tentang kelayakan dari berita itu sendiri. Ditambah lagi, pembingkaian SKM sebagai produk yang dapat menyebabkan karies gigi, obesitas, dan diabetes ini baru muncul pada tahun 2017. Pembingkaian ini juga hanya berdasarkan kutipan yang tidak menyertakan hasil penelitian ilmiahnya. Padahal, sebagai suatu informasi yang baru dan dapat berdampak pada kesehatan masyarakat luas, selazimnya informasi ini didukung oleh fakta ilmiah dari hasil penelitian terkini. Tanpa dukungan sumber informasi yang terpercaya,pembingkaian semacam ini bisa dianggap mengabaikan unsur verifikasi faktual dalam prinsip kerja jurnalistik. $^{18,19}$

Dari sisi proporsi sentimen artikel padamedia daring yang menjadi obyek penelitian ini, Kompas didapati menjadi media yang proporsi artikel dengan sentimen negatifnya terbesar dibandingkan dengan total artikelnya (19\% negatif, 5\% positif, sisanya netral), disusul oleh Tempo (10\% negatif, $2 \%$ positif, sisanya netral), Detik ( $8 \%$ negatif, $5 \%$ positif, sisanya netral), dan Vemale (4\% negatif, $11 \%$ positif, sisanya netral). Proporsi artikel dengan sentimen negatif yang variatif menunjukkan perbedaan agenda media yang layak untuk diteliti lebih lanjut.

Sementara dari sisi jenis artikelnya, Kompas menjadi media dengan proporsi artikel berita/opini paling besar dibandingkan dengan total artikelnya (37\%), disusul oleh Detik (29\%), Tempo (24\%), dan Vemale (7\%). Selain itu, Kompas juga menjadi media yang paling banyak melakukan pembingkaian negatif terhadap SKM (23 kali), disusul oleh Detik (15 kali), Tempo (8 kali), dan Vemale (5 kali). Temuan-temuan ini layak untuk melandasi dilakukannya penelitian lanjutan, terutama mengingat Kompas adalah kelompok media yang bukan hanya terbesar dan tertua di Indonesia saat ini, tapi juga karena Kompas selama ini dikenal sebagai media yang teguh 
dalam menjalankan pakem dan nilai-nilai

Tabel 5. Pembingkaian berdasarkan tahun

\begin{tabular}{lcc}
\hline Pembingkaian & 2016 & 2017 \\
\hline $\begin{array}{l}\text { Bingkai negatif } \\
\text { Karies gigi }\end{array}$ & 0 & 1 \\
Pencernaan & 1 & 0 \\
Obesitas & 0 & 10 \\
Diabetes & 0 & 7 \\
Bukan susu & 1 & 6 \\
Tinggi lemak & 3 & 2 \\
Tinggi kalori/gula & 6 & 14 \\
\hline Bingkai netral & & \\
Resep hidangan & 159 & 131 \\
Promosi produk & 13 & 4 \\
\hline Bingkai positif & & \\
Sumber energi \& protein & 1 & 5 \\
Sesuai aturan & 0 & 3 \\
Terjangkau & 11 & 11 \\
Bahan makanan pokok & 3 & 9 \\
Meningkatkan cita rasa & 31 & 21 \\
\hline
\end{tabular}

\section{Keterbatasan Penelitian}

Penelitian ini memiliki sejumlah keterbatasan yang perlu dipahami dalam membaca hasilnya. Pertama, metode analisis isi tidak dimaksudkan untuk menyimpulkan hubungan kausalitas. Penelitian ini juga hanya bersifat deskriptif-eksploratif, sehingga juga tidak dimaksudkan untuk menyimpulkan hubungan asosiasi. Paparan deskriptif dipilih mengingat belum banyak penelitian tentang produk pangan dalam kaitannya dengan ilmu gizi dan kesehatan masyarakat yang menggunakan metode analisis isi kuantitatif, sehingga penelitian-penelitian lanjutan sangat direkomendasikan. Kedua, penelitian ini juga membatasi pada artikel mengenai SKM sebagai produk turunan dari susu. luhur jurnalistik. ${ }^{20}$

Perbandingan antara artikel mengenai SKM dengan produk susu lainnya, atau dengan produk pangan lainnya, dapat memberikan pemahaman tambahan mengenai pembingkaian produk pangan. Terakhir, penelitian ini juga membatasi sumber artikel hanya pada media daring. Meskipun keempat media daring yang diteliti merupakan media yang cukup populer di Indonesia, membandingkannya dengan artikel terbitan media cetak dapat memperkaya pembahasan hasil penelitian.

\section{Kesimpulan}

Dari hasil penelitian ini ditemukan adanya pengabaian terhadap beberapa prinsip baku jurnalisme - seperti pemenuhan unsur dampak (significance), dan kesegeraan (urgency) dalam menentukan kelayakan berita-dalam artikel-artikel media daring mengenai SKM. Pembingkaian SKM secara negatif juga ditemukan kurang memenuhi unsur verifikasi faktual dalam kerja jurnalistik. Penelitian lanjutan dengan pendekatan politik ekonomi media layak untuk dilakukan untuk menggali lebih dalam mekanisme maupun motif media daring dalam membuat artikel tentang produk pangan.

\section{Daftar Referensi}

1. McCombs ME, Shaw DL. The Agenda-Setting Function of Mass Media. Public Opin $Q$. 1972;36:176-187. doi:10.2307/2747787.

2. Cobb RW, Elder CD. Participation in American Politics: The Dynamics of AgendaBuilding. 2nd ed. Johns Hopkins University Press; 1983.

3. Gitlin T. The Whole World is Watching: Mass Media in the Making \& Unmaking of the New Left. University of California Press; 1980.

4. Gamson WA, Modigliani A. Media Discourse and Public Opinion on Nuclear Power: A Constructionist Approach. Am J Sociol. 1989;95(1):1-37. doi:10.2307/2780405.

5. Entman RM. Framing Bias: Media in the Distribution of Power. J Commun. 
2007;57(1):163-173. doi:10.1111/j.14602466.2006.00336.x.

6. Entman RM. Media framing biases and political power: Explaining slant in news of Campaign 2008. Journalism. 2010;11(4):389408. doi:10.1177/1464884910367587.

7. Bedingfield S, Anshari D. Thinking about Romney: Frame Building in a Battleground State in the 2012 Presidential Election. Journal Mass Commun Q. 2014;91(1):78-97. doi:10.1177/1077699013514417.

8. Price V, Tewksbury D, Powers E. Switching Trains of Thought. Communic Res. 1997;24(5):481-506. doi:10.1177/009365097024005002.

9. Tuchman G. Making news: a study in the construction of reality. Free Press; 1978.

10. Mencher M. Basic Media Writing. McGrawHill College; 1998.

11. Dominick JR. The Dynamics of Mass Communication: Media in Transition. McGraw-Hill; 2012.

12. Craft S, Davis CN. Principles of American Journalism: An Introduction. Taylor \& Francis; 2016.
13. Pavlik J V, McIntosh S. Converging Media: A New Introduction to Mass Communication. Oxford University Press; 2016.

14. Potter WJ. Media Literacy. SAGE Publications; 2015.

15. Kementerian Perindustrian dan Perdagangan. Keputusan Menteri Perindustrian dan Perdagangan No. 115 tahun 1998 tentang Jenis Barang Kebutuhan Pokok Masyarakat.; 1998.

16. Badan Pengawas Obat dan Makanan. Peraturan Kepala BPOM No.1 tahun 2015 tentang Kategori Pangan.; 2015.

17. Krippendorff K. Reliability in Content Analysis: Some Common Misconceptions and Recommendations. Hum Commun Res. 2004;30(3):411-433. doi:10.1093/hcr/30.3.411.

18. Kovach B, Rosenstiel T. The Elements of Journalism. 3rd ed. Three Rivers Press; 2014.

19. Giles B. "The Elements of Journalism." Nieman Reports. 2001;55(2):36.

20. Oetama J. Pers Indonesia: Berkomunikasi dalam Masyarakat Tidak Tulus. Penerbit Buku Kompas; 2001. 